\title{
Study of the processes of distribution and deposition of hazardous substances of the first hazard class in the south of the Baikal region
}

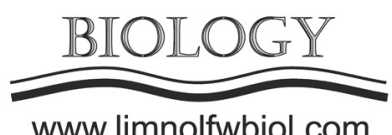

www.limnolfwbiol.com

\author{
Makukhin V.L. ${ }^{1,2 *}$, Latysheva I.V. ${ }^{2}$, Sinyukovich V.N. ${ }^{1}$ \\ ${ }^{1}$ Limnological Institute, Siberian Branch of the Russian Academy of Sciences, Ulan-Batorskaya Str., 3, Irkutsk, 664033, Russia \\ ${ }^{2}$ Irkutsk State University, K. Marx Str., 1, Irkutsk, 664003, Russia
}

\begin{abstract}
Using the example of mercury and lead, we discuss the results of the calculations of the distribution and deposition of hazardous substances of the first hazard class in the atmosphere of the Angara and Baikal regions, which were obtained through a mathematical model. We indicate that the enterprises in Slyudyanka and Baikalsk mainly contribute to the pollution of Southern Baikal with mercury; their contribution is $72 \%$. The remaining mercury input comes from the Irkutsk-Cheremkhovo industrial complex.

The enterprises in Slyudyanka and Baikalsk also mainly contribute to the pollution of Lake Baikal with lead (59-79 \%). The contribution of the Irkutsk-Cheremkhovo industrial complex and the sources located in the valley of the Selenga River is much lower due to their remoteness.
\end{abstract}

Keywords: distribution of impurities, atmosphere, mercury, lead

The Irkutsk Region is one of the most hazardous Russian regions in terms of mercury pollution. The main technogenic sources of its emissions are nonferrous metallurgical plants, enterprises for the extraction and processing of various metal ores as well as chemical and electrochemical industries.

The highest emissions of lead into the atmosphere occur at the enterprises of non-ferrous metallurgy, mechanical engineering, fuel and energy and chemical complexes, glass and canning industries. The proportion of technogenic lead in natural environments exceeds by one-two orders of magnitude its natural background values.

In this study, we discuss the processes of distribution and deposition of heavy metals of the first hazard class in the Angara and Baikal regions using the example of mercury and lead. We used the mathematical model of distribution and transformation of impurities, which was successfully applied in studies of the processes of distribution and transformation of solid suspensions, sulfur and nitrogen compounds in the Baikal region (Makukhin et al., 2016; Potemkin et al., 2019).

Industrial objects of such cities as UsolyeSibirskoye, Angarsk, Shelekhov, Irkutsk, Slyudyanka, and Baikalsk served as the source of $\mathrm{Hg}$ emissions. The processes of distribution were modelled at the site with an area of $200 \times 200 \mathrm{~km}^{2}$ and a height of $4 \mathrm{~km}$ above the surface of Lake Baikal. The time and horizontal steps were $150 \mathrm{~s}$ and $1 \mathrm{~km}$, respectively; the vertical step up to a height of $350 \mathrm{~m}$ was $50 \mathrm{~m}$, then $-150,500,1000$, and $2000 \mathrm{~m}$. The turbulent diffusion coefficients were calculated using the ratios of the semiempirical theory of turbulence (Arguchintsev and Arguchintseva, 2007). Industrial enterprises and complexes located in the valley of the Angara and Selenga rivers, on the coast of Southern Baikal and near Lake Gusinoye served as the sources of lead emissions. Numerical experiments were carried out at the site of an area of $500 \times 250 \mathrm{~km}^{2}$ and a height of $3 \mathrm{~km}$ above the surface of Lake Baikal. The time and horizontal steps were $150 \mathrm{~s}$ and $5 \mathrm{~km}$, respectively; the vertical step up to a height of 1000 $\mathrm{m}$ above the Baikal level was $50 \mathrm{~m}$, then - 250, 750 and $1000 \mathrm{~m}$. The turbulent diffusion coefficients were calculated using the ratios of the semiempirical theory of turbulence.

Comparison of the calculated $\mathrm{Hg}$ concentrations with the data on the measurements of mercury in the atmosphere of the studied region (Alyokhin et al., 2007) in order of magnitude indicated satisfactory agreement. The estimates of the intensity of the $\mathrm{Hg}$ deposition on the underlying terrain in the Southern Baikal region based on the calculated fields of the mercury concentrations were in satisfactory agreement with the state monitoring data on the mercury concentration in the snow at the reference stations of the Southern Baikal region.

In the Angara and Baikal regions, the enterprises

*Corresponding author.

E-mail address: aerosol@lin.irk.ru (V.L. Makukhin)

(C) Author(s) 2020. This work is distributed under the Creative Commons Attribution 4.0 License. 
in Slyudyanka and Baikalsk dominate in terms of the contribution to the pollution of Southern Baikal with mercury from atmospheric emissions: their proportion is $72 \%$. The contribution of the Irkutsk-Cheremkhovo industrial complex is much lower and equals to 28 $\%$, which is due to the remoteness of the emission sources from the lake and the presence of orographic inhomogeneities that impede the transfer of the impurities. During northwesterly wind at a speed of 2 $\mathrm{m} / \mathrm{s}$, the Primorsky Ridge and Olkhinsky Plateau retain a third of mercury from the lake.

Within a radius of $5 \mathrm{~km}$, approximately $10 \%$ of the gross mercury is deposited from a single source, which corresponds to the results of other researchers.

The calculations revealed that 9.2 tons of lead is deposited on the surface of Southern Baikal per year. In order of magnitude, there is a good agreement with the estimates based on the measurement data (Anokhin et al., 1981; Belova et al., 1987). The enterprises in Slyudyanka and Baikalsk also mainly contribute to the pollution of Lake Baikal with $\mathrm{Pb}$ (59-79\%). The contribution of Irkutsk-Cheremkhovo industrial complex varies from 10 to $12 \%$ in autumn and winter and up to $38 \%$ in spring. The influence of the sources located in the valley of the Selenga River is the lowest: from $3 \%$ in spring and summer to $10-13 \%$ in autumn and winter.

The obtained results can be used to address issues of improving the ecological situation in the region and regulating the operation of enterprises.

\section{References}

Alyokhin Yu.V., Lapitsky S.A., Mukhamadiyarova R.V. et al. 2007. New results of the study of individual components of the geochemical cycle of mercury. Vestnik Otdeleniya Nauk o Zemle RAN [Bulletin of the RAS Department of Earth Sciences] 1(25): 1-4. (in Russian)

Anokhin Yu.A., Ostromogilskiy A.Kh., Poslovin A.L. et al. 1981. Assessment of the anthropogenic flow of trace elements from the atmosphere to Lake Baikal. Problemy Ekologicheskogo Monitoringa i Modelirovaniya Ekosistem [Problems of Ecological Monitoring and Modelling of Ecosystems] IV: 32-40. (in Russian)

Arguchintsev V.K., Arguchintseva A.V. 2007. Modelirovaniye mezomasshtabnykh gidrotermodinamicheskikh protsessov i perenosa antropogennykh primesey $\mathrm{v}$ atmosfere i gidrosfere regiona oz. Baikal [Modeling of mesoscale hydrothermodynamic processes and transport of anthropogenic impurities in the atmosphere and hydrosphere of the Baikal region]. Irkutsk: ISU Publishing House. (in Russian)

Belova N.I., Kokorin A.O., Ostromogilskiy A.Kh. 1987. Modelirovaniye i prognosticheskiye otsenki balansa mikroelementov $\mathrm{v}$ ozere Baikal [Modeling and predictive assessments of the balance of trace elements in Lake Baikal]. Leningrad: Gidrometeoizdat. (in Russian)

Makukhin V.L., Obolkin V.A., Potemkin V.L. et al. 2016. Estimates of the spatial distribution of trace gases over the water area of Lake Baikal in the summer using field measurements and the results of mathematical modeling. Izvestiya Irkutskogo Gosudarstvennogo Universiteta. Seriya: Nauki o Zemle [Irkutsk State University Bulletin. Series: Earth Sciences] 18: 69-80. (in Russian)

Potemkin V.L., Latysheva I.V., Makukhin V.L. et al. 2019. Characteristics of the vertical distribution of aerosols and gas impurities in the Lake Baikal region. Izvestiya Irkutskogo Gosudarstvennogo Universiteta. Seriya: Nauki o Zemle [Irkutsk State University Bulletin. Series: Earth Sciences] 27: 111-121. (in Russian) 